\title{
A REVIEW OF THE DISTRIBUTION AND BIOLOGY OF THE SMALL CARRION BEETLE PRIONOCHAETA OPACA OF NORTH AMERICA (COLEOPTERA; LEIODIDAE; CATOPINAE)*
}

\author{
By Stewart B. Peck \\ Department of Biology, Carleton University, \\ Ottawa Ontario K1S 5B6 Canada
}

With the continued interest shown by ecologists in studies of carrion insects it is now appropriate to present a summary of the known distribution and biology of Prionochaeta opaca, one of the most frequently encountered species of the Catopinae, the small carrion beetles. This paper is number 17 in a continuing series on the systematics, biology, and evolution of the catopine beetles of the Americas.

Prionochaeta opaca is the only North American member of the otherwise large Eurasian tribe Cholevini (sensu Jeannel, 1936; Szymczakowski, 1964). The genus Prionochaeta was erected by Horn (1880) to contain the North American species described as Catops opacus by Say (1825). Since then, three other species of Prionochaeta have been described from Asia: also in the opaca group is $P$. sibirica Reitter from southeastern Siberia; and in the harmandi group is $P$. harmandi Portevin from Japan, and $P$. roubali Hlisnikowski from Szechwan, China.

Diagnostic Description. From most other small beetles commonly occurring at carrion or other decomposing matter, the Catopinae can be distinguished by their antennae, having a five segmented club with segment 8 smaller than segments 7 and 9. $P$. opaca is easily separated from all other American catopines by the following combination of characters: It is the largest catopine in eastern North America (ranging from 4 to $5.5 \mathrm{~mm}$ in length in a normally reflexed condition). The pronotum and elytra have neither striae nor a coarsely granular surface, but are covered with abundant setae with prominent basal sockets. Males have expanded front tarsal segments but the first tarsal segment of the middle leg of males is not enlarged or swollen (a character of the tribe Catopini). The elytra appear to have a pale blue-grey pru-

*Manuscript received by the editor December 22, 1977 
inose surface when viewed with a strong light at a low angle (caused by diffraction of light on the finely striate surface of small scales) but otherwise the species is of a reddish-to-dark brown color. The most distinctive character is the very long spur on the hind tibia. The spur is longer than the first metatarsal segment and has distinctly serrated fringes on two margins. Other descriptive and taxonomic details can be found in Horn (1880), Hatch (1930), Jeannel (1936), and Szymczakowski (1964), and in figures 1-7.

Variation. Except for differing body sizes, no morphological variation is evident in specimens from throughout the range of the species. On the male genitalia, differing degrees of sclerotization of the paramere tips causes them to twist to differing amounts when dried. The setae on the internal face and ventral margin of the paramere tips (not drawn in figs. 6, 7) do not vary.

Geographic distribution. The species has a wide distribution over most of the region covered by the deciduous broad-leaf forest of temperate eastern North America (fig. 8). Over this area the elevational range of the species is from coastal plain lowlands to upper elevations in both the North and South, from the White Mountains of New Hampshire to the Great Smokey and Black Mountains of North Carolina. The map is based upon specimens in the following collections (personal observation): Snow Museum (University of Kansas); Field Museum; California Academy of Sciences; Blatchley collection of Purdue University; Michigan State University; Cornell University; University of Alabama (Museum of Natural History); Museum of Comparative Zoology; U.S. National Museum of Natural History; Illinois Natural History Survey; Canadian National Collection (Ottawa); and Claude Chantal (Quebec City). These collections contain about 400 specimens. My own collection included 1200 specimens. Many of these are now deposited in the MCZ, Field Museum, and Canadian National Collection. Literature records of Blatchley (1910), Brimley (1938), Leonard (1926) and Kirk (1969) have also been used on the map because they are probably correct in reporting on this distinctive species. The imprecise record for "southwestern Arkansas" of Hatch (1933) and the doubtful record of Jeannel (1936) for Breckinridge, Colorado, have not been used.

The forest population near Marianna in Jackson county in northern Florida is probably disjunct and relictual. The Marianna lowlands is known as a floristic relict area (Mitchell, 1963) and a 


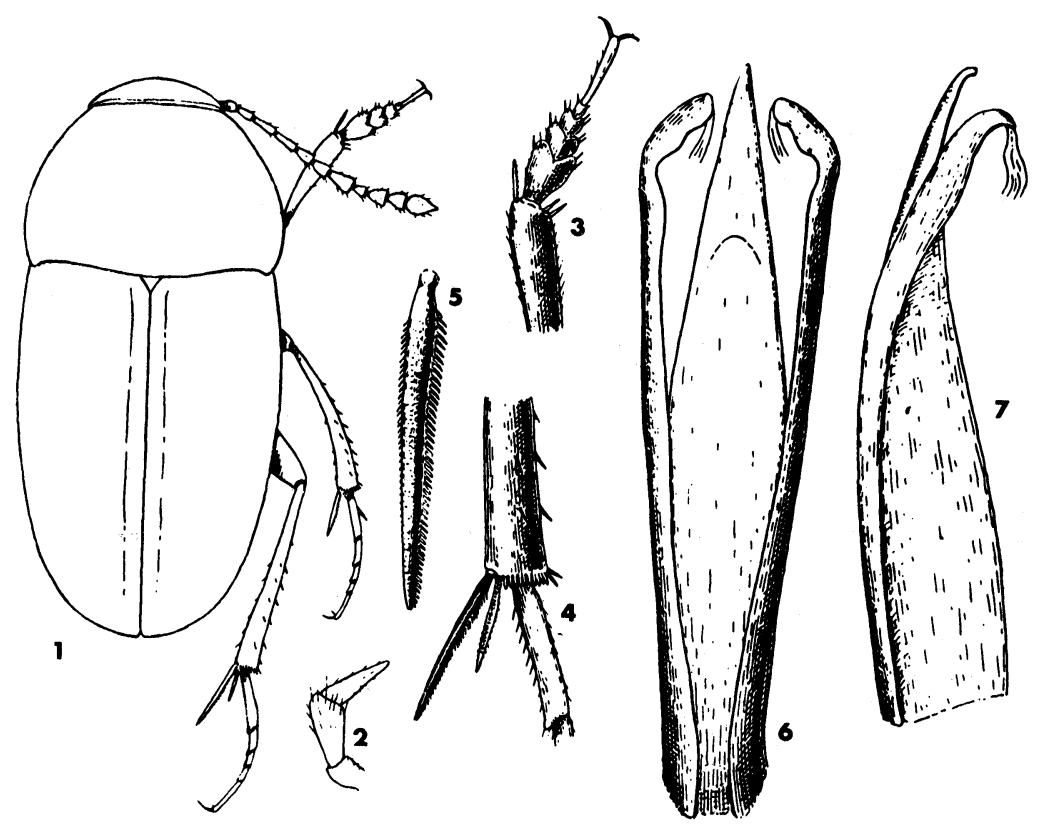

Figures 1-7. Structures of Prionochaeta opaca Say. 1. Habitus of male. 2. Left maxillary palp. 3. Protibial tip and enlarged male protarsus. 4. Mesotibial tip and unexpanded male mesobasitarsomere. 5. Large internal spur of posterior tibia. 6. Dorsal view of aedeagus, setae on internal face of parameres omitted. 7. Lateral view of aedeagus. From Jeannel, 1936.

similar situation is suggested for many arthropods (personal data). The species probably does not occur in peninsular Florida because extensive trapping there by Dr. Altred Newton and myself has failed to find it. Another disjunct population is in the forested Black Hills of western South Dakota. This population is separated from the rest of the species' range to the east by the grasslands of the Great Plains. The beetle undoubtedly reached the Black Hills when the intervening country was more forested (with at least more extensive streamside gallery forests) during a cooler and more moist glacial period. It has become isolated with the expansion of the prairies in the warmer and drier climate of the present interglacial.

Habitat preferences and feeding biology. Most specimen records show that the preferred habitat of the species is in moist and 


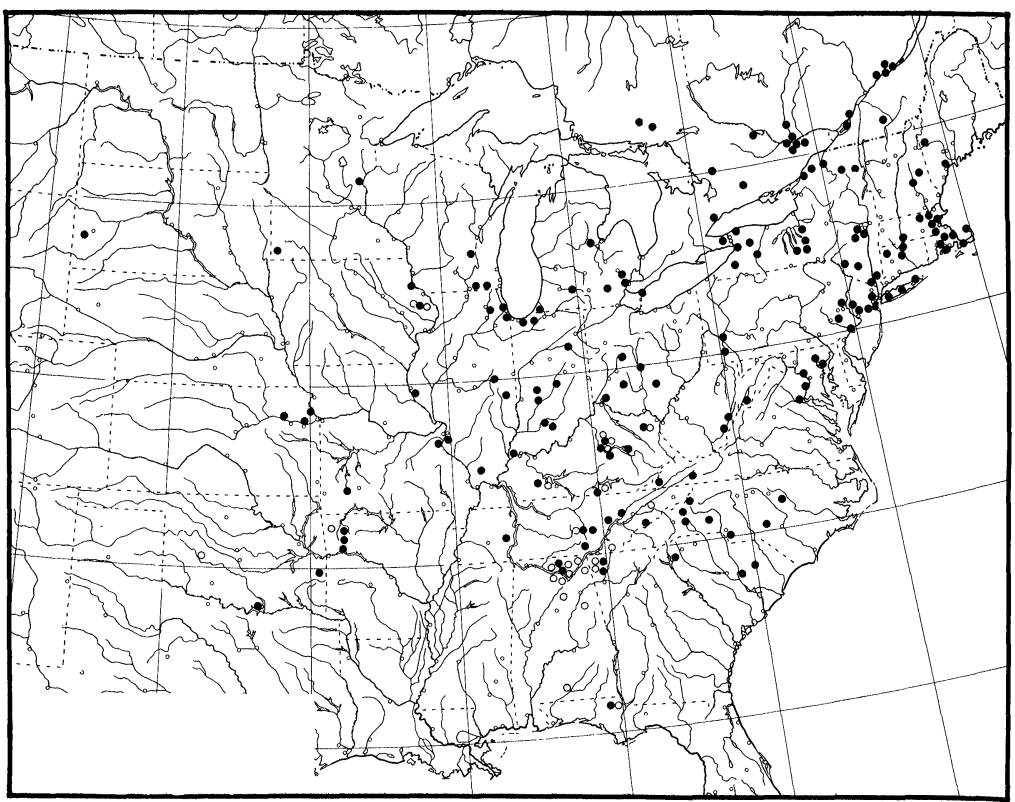

Figure 8. Map of distribution of Prionochaeta opaca Say. Closed dots, epigean records. Open dots, cave records. A dot may indicate more than one county locality record. Disjunct forest populations occur in the Black Hills of South Dakota, and in northern Florida. These and the prevalence of cave records in the south indicate adjustment of the species' range to post-glacial climatic conditions.

forested situations. Experimental field studies back this up. Walker (1957) took P. opaca during systematic trapping in Tennessee only in mesic and bottom forest, and not in drier ridge forest and old field habitats. Reed (1958) found the species in Tennessee on carrion in forests but never in pastures. Within a single mesic forest there is probably little microhabitat preference. Pirone (1974), in a trapping study in New York, collected about equal numbers of beetles in both forested slope and level sites. Shubeck (1969) found the species to be more common in a shrub community of arrowwood and greenbrier than in maple-leaved viburnum and black-haw shrub areas, in a New Jersey oak-hickory climax forest.

Wherever the beetle has been collected it seems to be a generalized scavenger on decaying organic matter, perhaps actually feed- 
ing on the fungi or bacteria associated with decomposition. It has been taken on carrion throughout its range and can be easily trapped with carrion baits (see above, and Newton and Peck, 1975). Shubeck (1969) noticed that $P$. opaca increased in numbers as other carrion beetles decreased, at a later stage of succession of the carrion fauna, when the carcass was drying out. In contrast, Johnson (1975) found the species in an Illinois forest to be most common in the decay stage of decomposition.

I have commonly taken $P$. opaca throughout its range in traps baited with human dung, and have found it on fox dung in Iowa. It occurs often in animal burrows and dens where it is probably a scavenger on nest or waste materials. So far, it have been recorded in literature and on specimen labels in woodchuck burrows in Indiana, New York, and Pennsylvania; in a fox hole in Massachusetts; in rabbit nests in Indiana; in a belted kingfisher nest in New York; and in a buzzard nest in Maryland. It has been taken by Berlese-Tulgren funnel processing of decaying plant debris from Florida to New York and Wisconsin, and in tree holes in Illinois and South Carolina. Decaying gill fungi and rotted puffballs have yielded it in Indiana, Kentucky, Maryland, Iowa, Illinois, and Massachusetts. The beetles prefer carrion over rotting fruits; Pirone (1974) took 462 specimens at fish carrion and only three at rotting melon in New York; Walker (1957) found this species only at fish carrion and not at rotting cantaloupe or cornmeal baits in Tennessee. Single occurrences in unusual places have been made under a kitchen sink in a Massachusetts house, in syrup traps in Virginia, by beating vegetation in Indiana, and from a tanglefoot screen and at blacklight in South Carolina.

$P$. opaca has been abundantly taken in the southern part of its range on carrion baits in cave habitats. I have observed the beetle in large and persistent populations feeding on moist bat guano and carcasses in Kentucky, and Florida, and Black (1971) reports the same in Oklahoma. The following specific cave sites are listed: Alabama. Blount Co., Catfish, Horseshoe-Crump, and Randolph caves. Calhoun Co., Robertson and Weaver caves. Conecuh Co., Turk Cave. DeKalb Co., Cherokee and Lois Killian caves. Jackson Co., House of Happiness and Rousseau caves. Madison Co., Burwell, Ellis, Hurricane, Matthews and Scott caves. Marshall Co., Eudy, Honeycomb, Merrill, Painted Bluff, and Terrill caves. Morgan Co., Lipscomb Cave. Arkansas. Washington Co., Cork- 
screw and Fincher caves. Florida. Jackson Co., Gerards and Miller (Florida Caverns State Park) caves. Georgia. Chatooga Co., Blowing Springs Cave. Walker Co., Bible Springs, Horseshoe, and Mountain Cove Farm caves (Holsinger and Peck, 1971). Iowa. Jackson Co., Barred (Maquoketa Caves State Park) and Hunters caves. Kentucky. Barren Co., Slick Rock Cave. Carter Co., Bat Cave (Carter Caves State Park). Clark Co., Jones Cave. Fayette Co., Phelps Cave. Russell Co., Rowe Cave. Scott Co., Slacks Cave. Oklahoma. Washita Co., Washita Bat Caves (Black, 1971). Tennessee. Bradley Co., Quarry Cave east of Cleveland. Cannon Co., Connell Creek, Davenport, and Highway Spring caves. Hamblen Co., Three Springs (Butry or Delap) Cave, 400 to 800 feet inside.

Seasonal activity. Data on specimen labels show the species to be active from March through November, in both northern and southern locations, with most specimens being taken from May to September. Generally, the more southerly populations are active earlier and later in the year. A few studies have experimentally followed the changes in abundances of the species throughout the year. Pirone (1974) found the species to be the most common catopid on carrion in southern New York; the beetles occurred from mid April through to November, and most were taken in August. Shubeck (1969), in a three year study in New Jersey, found the species to have differing abundances through the summer but to be most common in early-middle summer. In a repeat study in the same forest (Shubeck, Downie, Wenzel, and Peck, 1977) the species was again found from April to November, with a midsummer peak in abundance. In Tennessee, Reed (1958) collected the beetle on dog carcasses from mid June to late August. In another Tennessee study, Walker (1957) took P. opaca in midsummer, but did not trap at other times. In a carrion study in an Illinois forest, Johnson (1975) found the beetle to appear in April and to be present through November, being most abundant in September. Larvae appeared at the end of the decay stage and were mostly associated with the dry stage; they occurred in May, were most common in July, and last appeared in September.

During one of his trapping programs in a New Jersey forest, Shubeck (1971) found all catopids (which he called leptodirids) including $P$. opaca, to be diurnally active, in June and August, and to have no nocturnal activity. 
A large number of cave populations are known. It could be expected that the beetles might be reproductively active in caves throughout much (if not all) of the year, because of the decreased seasonal variation of climatic factors in cave environments. However, collections or observations are not adequate enough to test this suggestion.

Reproduction. Larvae for the species have been long known, and are illustrated in Boving and Craighead (1931). Although it should not be difficult to keep and rear the beetles (methods in Peck, 1973, 1975) I know of no data on eggs, egglaying, or larval stages and their biology, other than Johnson's (1975) observation that larvae are most commonly associated with the dry stage of decomposition.

Evolution and Biogeography. The distribution of Prionochaeta and of other members of the Cholevini suggests that they originated in the Old World. Probably only one species of Prionochaeta migrated into the New World across a Bering land bridge in the Tertiary (see Hopkins, 1967, for a discussion of the Tertiary Bering Bridge). Although the genus must then have lived in western North America, it became extinct there (probably by the Pleistocene), and survived only in eastern North America. The resulting generic distribution in eastern North America and in eastern Asia is a not uncommon type of disjunct pattern (Darlington, 1957). It is believed here that the abundance of cave populations in the southern part of the species range is a reflection of distributional adjustments in the present post-glacial. Since the beetles apparently require a cool and moist temperate habitat, as climatic conditions have warmed, the beetles have become less able to survive in the now less-temperate southern forests where they lived during the Wisconsinan glacial. Caves, with their seasonally more uniform, cool and moist conditions, have thus become Recent southerly refugia for this beetle (although some southern forest populations yet remain) as they have for several other insects (Peck and Russell, 1976).

\section{ACKNOWLEDGEMENTS}

Henry Dybas, Hugh B. Leech, Vern Pechuman, John Lawrence, Herbert Boschung, John Kingsolver, Milton W. Sanderson, Roland L. Fischer, and J. M. Campbell allowed study of the collections under their care. 
Alfred F. Newton, Walter Suter, and Quentin D. Wheeler generously contributed material to my collection. The many people, too numerous to mention individually, that have helped me with field work are thanked. Field work support has been provided by the U.S. National Science Foundation through the Evolutionary Biology Committee of Harvard University and by operating grants from the Canadian National Research Council. Dr. Newton has reviewed the manuscript.

\section{Literature Cited}

BLACK, JEFFREY H.

1971. The cave life of Oklahoma, a preliminary study (excluding Chiroptera). Oklahoma Underground, J. Cent. Oklahoma Grotto, National Speleological Society, Oklahoma City. 4(1 \& 2): 2-53.

Blatchley, W. S.

1910. An illustrated descriptive catalogue of the Coleoptera or beetles known to occur in Indiana. Ind. Dept. Geol. and Nat. Res., Bull. 1, 1386 pp. Nature Publ. Co., Indianapolis.

Boving, A. C. And F. C. Craighead.

1933. An illustrated synopsis of the principal larval forms of the order Coleoptera. Entomologica Americana, XI. 351 pp. 1973 reprint edition. Brooklyn Entomol. Soc.

BRIMLEY, C. S.

1938. Insects of North Carolina. Div. Entomol., North Carolina Dept. Agric., Raleigh. 560 pp.

DARLington, P. J.

1957. Zoogeography: the geographical distribution of animals. John Wiley \& Sons, New York. 675 pp.

НАТсн, М. H.

1933. Studies on the Leptodiridae (Catopidae) with descriptions of new species. Jr. New York Ent. Soc. 41: 187-239.

Holsinger, J. R. AND S. B. PeCK

1971. The Invertebrate Cave Fauna of Georgia. Natl. Speleol. Soc. Bull. 33: 23-44. HopkINS, D. M.

1967. The Cenozoic history of Beringia - A Synthesis. pp. 451-484, in Hopkins, D. M. (ed.), the Bering Land Bridge. Stanford Univ. Press, Stanford, California. 495 pp.

HorN, G. H.

1880. Synopsis of the Silphidae of the United States. Trans. Amer. Entomol. Soc., 8: 219-322.

JEANNEL, R.

1936. Monographie des Catopidae. Mem. Mus. Nat. Hist. Natu., Paris, nouv. ser., 1, 433 pp.

Johnson, Michael D.

1975. Seasonal and microseral variation in the insect populations on carrion. Amer. Midl. Nat., 93: 79-90. 
KiRK, VERNON M.

1969. A list of beetles of South Carolina, part 1, northern coastal plain. South Carolina Agric. Exp. Stat., Clemson Univ., Tech. Bull. 1033. LEONARD, M. D.

1926. A list of the insects of New York, with a list of spiders and certain other allied groups. Cornell Univ. Agric. Exp. Sta. Mem. 101.

MitChELl, RichaRd S.

1963. Phytogeography and floristic survey of a relic area in the Marianna lowlands, Florida. Amer. Midl. Natur., 69: 328-366.

Newton, A. AND S. B. PeCK

1975. Baited pitfall traps for beetles. Coleop. Bull. 29: 45-46.

PeCK, S. B.

1970. The terrestrial arthropod fauna of Florida caves. Florida Entomol. 53: 203-207.

1973. A systematic revision and the evolutionary biology of the Ptomaphagus (Adelops) beetles of North America (Coleoptera, Leiodidae; Catopinae), with emphasis on cave-inhabiting species. Bull. Mus. Comp. Zool., Harvard, 145(2): 29-162.

1975. The life cycle of a Kentucky cave beetle, Ptomaphagus hirtus (Coleoptera, Leiodidae, Catopinae). Int. J. Speleology, 7: 7-18.

PeCK, S. B. AND D. R. Russell

1976. Life history of the fungus gnat Macrocera nobilis in American caves (Diptera; Mycetophilidae). Can. Ent., 108: 1235-1241.

PIRONE, D. J.

1974. Ecology of necrophilous and carpophilous Coleoptera in a southern New York woodland (phenology, aspection, trophic, and habitat preferences). 769 pp. Ph.D. dissertation, Fordham University. Xerox University Microfilms, 74-25078, Ann Arbor, Mich.

REED, H. B., JR.

1958. A study of dog carcass communities in Tennessee, with special reference to the insects. Amer. Midl. Natur., 59: 213-245.

SAY, T.

1825. Descriptions of new species of coleopterous insects inhabiting the United States. J. Acad. Nat. Sci. Philadelphia, 5: 160-202.

Shubeck, Paul P.

1969. Ecological studies of carrion beetles in Hutcheson Memorial Forest. J. New York Ent. Soc., 77: 138-151.

1971. Diel periodicities of certain carrion beetles (Coleoptera:Silphidae). Coleopterists Bull., 25: 41-46.

Shubeck, Paul P., N. M. Downie, R. L. Wenzel, and S. B. Peck.

1977. Species composition and phenology of carrion beetles in a New Jersey mixed-oak forest. Hutcheson Mem. For. Bull., in press.

SZYMCZAKOWSKI, W.

1964. Analyse systematique et zoogeographique des Catopidae (Coleoptera) de la region orientale. Acta Zool. Cracoviensia, 9(2): 55-289.

WALKer, ThOMAS J., JR.

1957. Ecological studies of the arthropods associated with certain decaying materials in four habitats. Ecology, 38: 262-276. 

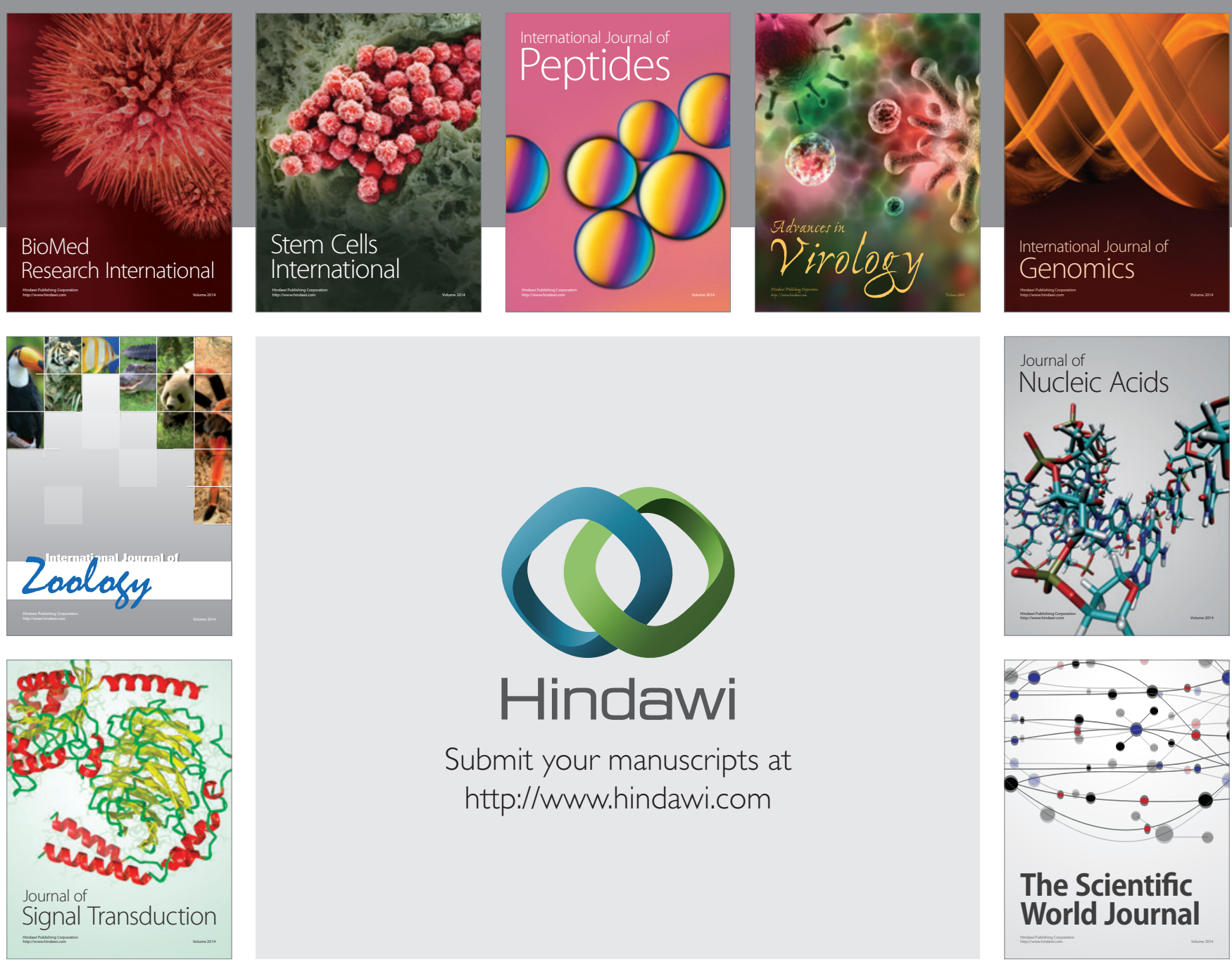

Submit your manuscripts at

http://www.hindawi.com
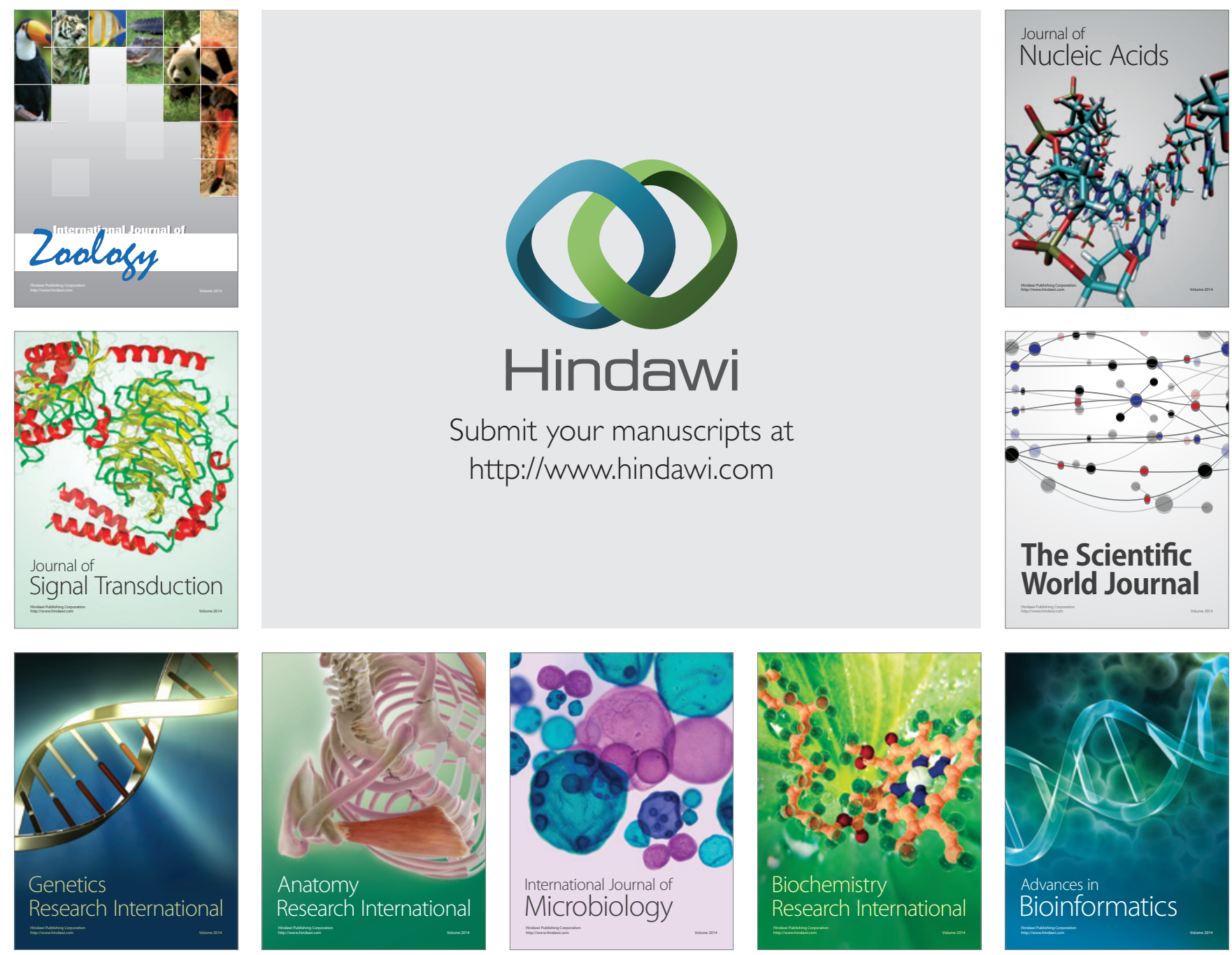

The Scientific World Journal
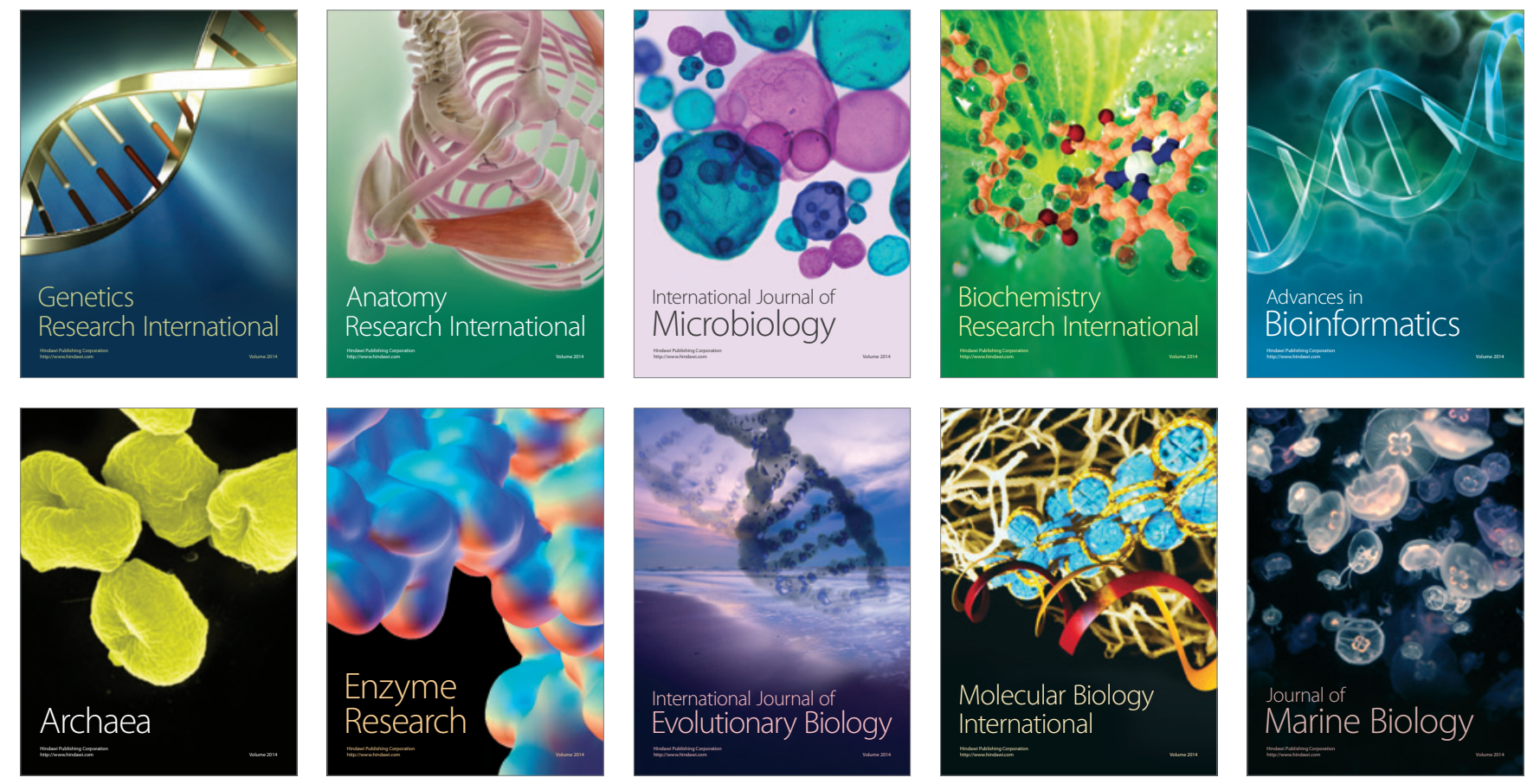